\author{
JULY 2016, VOLUME 4, ISSUE 3, 1 - 12 \\ E-ISSN NO: $2289-4489$
}

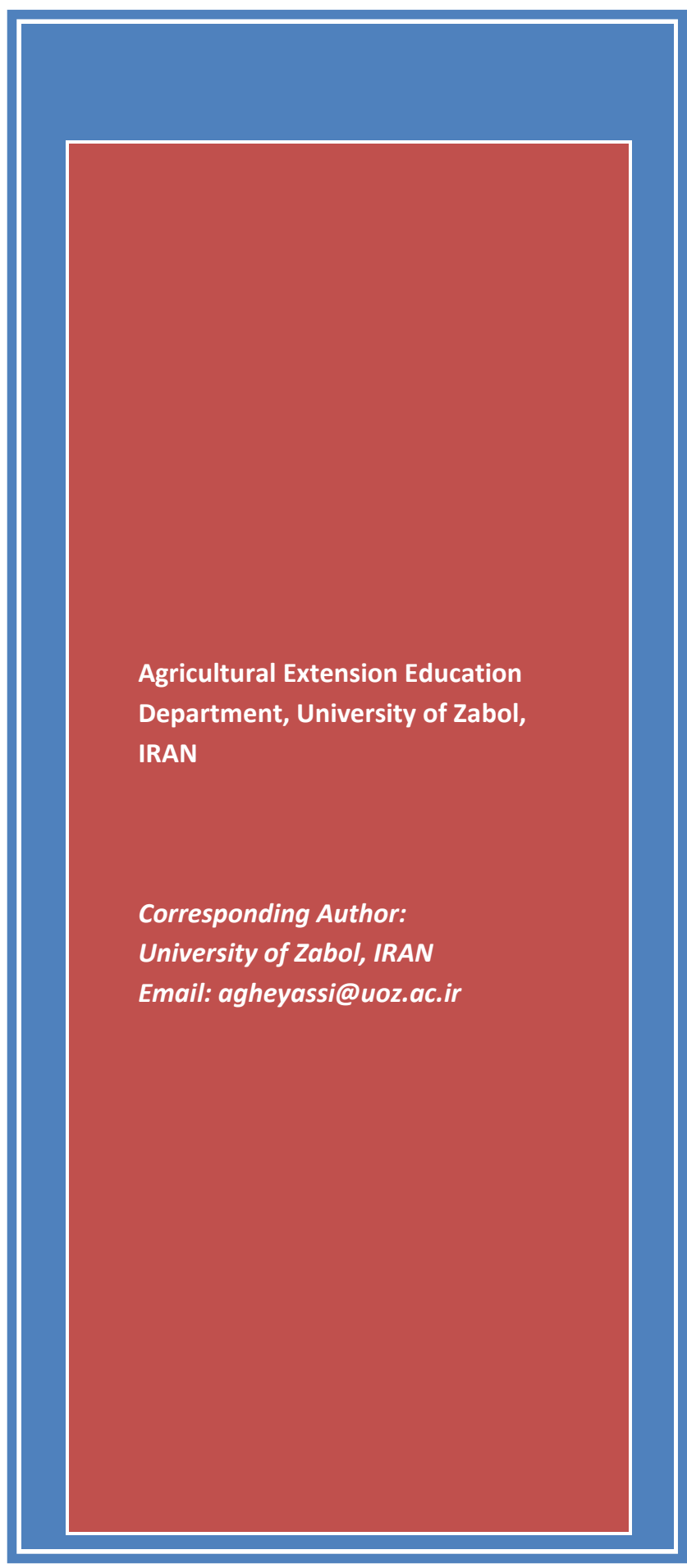

\title{
THE EFFECT OF SELF-EFFICACY AND SELF-ESTEEM ON TENDENCY FOR ENTREPRENEURSHIP AMONG UNIVERSITY STUDENTS
}

\section{Abdolrahim Gheyassi}

\begin{abstract}
This is a descriptive-correlation research design aimed at investigating the impact of belief in self-efficacy and self-esteem on the tendency for entrepreneurship among university students. The statistical population included all 3000 undergraduate and postgraduate students studying agriculture and natural resources at the University of Zabol in Iran. Using Cochran's formula and the random sampling method with probability proportional to size, 210 students were selected as the sample. The data collection instrument was a survey questionnaire. Validity of the questionnaire was reviewed and approved by a group of experts. Cronbach's alpha was used to test the reliability of the measuring instruments. Values obtained were $.83, .86$, and .74 for the tendency for entrepreneurship, self-efficacy belief, and self-esteem, respectively. Data analysis was done using SPSS(V.21). Results from correlation analysis revealed a positive and significant relationship between self-efficacy beliefs and the tendency for entrepreneurship among university students. Moreover, the findings of multiple regression analysis indicated that $27 \%$ of the variance of dependent variable explains the tendency for entrepreneurship through self-efficacy belief.
\end{abstract}

Keywords: Self-Efficacy, Self-Esteem, Tendency, Entrepreneurship, Students, University, Iran 


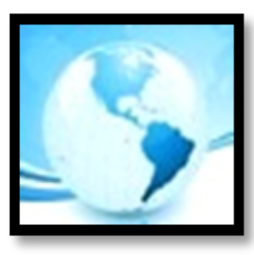

\section{INTRODUCTION}

Manpower is considered to be the most important and effective factor in development in many countries (Mojarradi et al., 2008). Therefore, training efficient manpower and entrepreneurs will also be a developmental factor. Given that students are the potential manpower in a society (Shokrkon et al., 2002), encouraging entrepreneurship among them, as the future-makers of the society, would result in sustainable human development. Hence entrepreneurship has been emphasized in many studies.

Currently, one of the paths for improving entrepreneurship lies in society, universities and higher-education institutions (Lucas \& Cooper, 2004); effective planning to train student entrepreneurs should be one of the main priorities in these institutions.

Considering that statistics indicate a high unemployment rate among agriculture and natural resources graduates, entrepreneurship is a solution that previous research has cited as a stable approach to resolving the unemployment problem (Faria, Cuestas, \& Mourelle, 2010; Remeikiene \& Startiene, 2015). In this regard, conducting research and studies on entrepreneurship for university students is of considerable importance to achieve the main principles of training entrepreneurial students.

Entrepreneurship literature indicates that the researches have studied different aspects of this subject. A very important aspect which has been less studied is the tendency for entrepreneurship in people. The tendency for entrepreneurship is important because it is a predicting factor influencing entrepreneurial behavior (Barani \& Zarafshani, 2009; Moriano \& Gogievski, 2007).

If entrepreneurship is defined as an activity including discovery, evaluation and exploitation of opportunities for new products and services, organization methods, and marketing processes and raw materials through organizing the newly invested efforts (Shane, Locke, \& Collins, 2003), the tendency for entrepreneurship should be defined as a desire in people to develop entrepreneurial behaviors such as creating and identifying opportunities and also using new methods (Waight, 2006).

Research indicates that many factors affect entrepreneurship and tendency for it, due to its complexity (Waight, 2006). One of the known factors influencing entrepreneurship and tendency for it is the psychological characteristics of individuals. Therefore, researchers (such as Javan, 2014; Mohamadi, Ebadallah, \& Jahromi, 2011; Zampetakis et al., 2008) have identified the impact and correlation of many psychological factors with respect to entrepreneurship and the tendency for it.

However, self-efficacy influences the type of activity individuals select (Chu, 2008). Confirming the impact of selfefficacy on individual choice, Pajares (1997) and Schunk (1995) state that it also influences effort, perseverance, and enthusiasm in individuals. Moreover, self-efficacy is a powerful predictor of development (Diseth, Meland, \& Breidablik, 2014; Wentzel, Wigfield, \& Miele, 2009). Lucas and Cooper (2004) believed that self-efficacy has great impact on the tendency of people to perform an entrepreneurial action through identifying and using opportunities.

Furthermore, high or low levels of self-efficacy have serious impacts on people's beliefs in their abilities to perform an action (Lucas \& Cooper, 2004). It means that the individuals with a higher self-efficacy deal with hardships with more diligence and perseverance (Chu, 2008). On the other hand, high self-efficacy is related to different behaviors such as innovation, identification of the opportunities, and entrepreneurship (Ardichvili, 2003). 


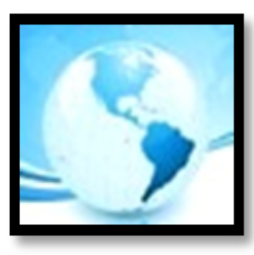

\section{MALAYSIAN ONLINE JOURNAL OF EDUCATIONAL MANAGEMENT (MOJEM)}

The relationship between self-efficacy and entrepreneurial behavior was proven in some research (Drnovsek \& Erikson, 2005). However, the relationship between the self-efficacy belief and the tendency for entrepreneurship is yet unconfirmed.

Luthans, Stajkovic, and Ibrayeva (2000) believed that self-efficacy beliefs in entrepreneurship was among the requirements considered necessary and indispensable to have entrepreneurial motivations and to make efforts for relevant actions. For instance, some individuals like performing new and entrepreneurial actions; however, they cannot do so, which is not due to inability or lack of necessary knowledge and skill, rather it is because of disbelief in abilities and skills (Luthans et al., 2000). Self- efficacy belief is a notion, which individuals have to achieve a specific level of performance and desired results based on their capacities and capabilities (Sharf, 2015). To Sharf (2015), individuals with strong self- efficacy belief hold that they can effectively deal with events and circumstances, show tenacity, and usually have a high performance level. The study conducted by Hassanpur, Hosseini and Safari (2013) indicated that self-efficacy was directly related to entrepreneurship tendency. Chen, Greene, and Crick (1998) also state that self-efficacy not only predicts entrepreneurial performance, but also determines entrepreneurship avoidance. Therefore, many individuals involved in transition economies may have the tendency for entrepreneurship, but they are not necessarily involved in entrepreneurial activities, as they are not adequately self-efficient (Luthans et al., 2000).

Another psychological factor influencing the behavior and success of people is self-esteem, which is used along with self-efficacy in many studies, due to having a strong relationship with it. However, a distinction should be made between self-esteem and self-efficacy because self-efficacy refers to the belief in ability and capacity, while self-esteem is made up of judgments and values, which people consider on their own (Christensen, Martin, \& Smyth, 2014).

Robinson et al. (1991) believe that self-esteem is a foundation of the tendency for entrepreneurship. The evidence indicates that a high level of self-esteem decreases anxiety (Pyszczynski et al., 2004; Sowislo \& Orth, 2013), and low self-esteem results in anxiety and loss (Plummer, 2014). Overcoming anxiety is one of the main characteristics of entrepreneurs (Mukhopadhyay et al., 2013). In this regard, some experts believe that high self-esteem is one of the characteristics of entrepreneurs (Welsh \& White, 1981). Also, the results in Shokrkon et al. (2002) indicated that self-esteem and self-efficacy were directly related.

Given the complexity of the tendency for entrepreneurship, it is assumed that individual and familial factors may also affect this tendency. For example, the entrepreneurship tendency is directly related to education level (Noorollahenoorivandi \& Mirdamadi, 2010). Strohmeyer (2003), Moog and Backes-Gellner (2003), and BackesGellner and Moog (2009) indicate that entrepreneurship tendency varies based on gender. Backes-Gellner and Moog (2013) found that being in contact with entrepreneurial parents has a positive relationship with the tendency for entrepreneurship.

Given that the two very important aspects of psychological studies are the self-efficacy belief and self-esteem, this paper aims at investigating the impacts of these two variables on student entrepreneurship tendency among students in the field of agriculture and natural resources.

Considering the great importance of training entrepreneurial students in higher-education institutions, specifically in agriculture and natural resources and given the results of the research on the important role of education in stimulating students' tendency for entrepreneurship (Kumar et al., 2013), the current research attempts to investigate the impact of self- efficacy belief and self-esteem on entrepreneurship tendency. Moreover, it also aims at identifying the entrepreneurship tendency level among the students of agriculture and natural resources. In this connection, the objectives of the current research are as follows: 


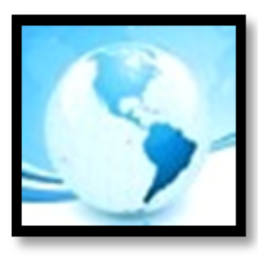

\section{MALAYSIAN ONLINE JOURNAL OF EDUCATIONAL MANAGEMENT (MOJEM)}

$-$

$-$

\section{METHODOLOGY}

This is a descriptive-correlational research. The statistical population included all 3000 undergraduate and postgraduate students studying agriculture and natural resources at University of Zabol in Iran $(\mathrm{N}=3000)$. Using the random sampling method with probability proportional to size and Cochran's formula, the sample size was estimated to be 210 individuals. The research instrument was a questionnaire consisting of four types of questions which were demographic ones, Scherer's self-efficacy questionnaire (1982), Rosenberg's self-esteem questionnaire (1965), and the questionnaire of tendency for entrepreneurship. The self-efficacy questionnaire designed by Scherer had 17 items graded with Likert scale ranging from strongly disagree (1), disagree (2), undecided (3), agree (4) and strongly agree (5) According to the questionnaire guideline, the lowest and highest grades obtained were 17 and 85, respectively. Rosenberg's self-esteem questionnaire had 10 items, some of which were stated as positive and some as negative. The questionnaire was graded with a four-point Likert scale ranging from 0 (strongly disagree) to 3 (strongly agree). According to the questionnaire guideline, the lowest and highest grades obtained were 0 and 30. Scores over 25 represented high self-esteem, while those between 15 and 25 stated average self-esteem, and scores under 15 indicated low self-esteem (Barkhordary, Jalalmanesh, \& Mahmodi, 2009). The fourth part which included a 20-item questionnaire with a five-grade Likert scale (ranging from strongly agree (1) to strongly disagree (5) evaluated the tendency for entrepreneurship.

To evaluate the tendency for entrepreneurship and self- efficacy belief among students and also to categorize them according to low (undesirable), average (rather desirable), and high (desirable) levels, the difference between standard deviation and mean (ISDM) was used as follows after collecting the responses to the items (Gangadharappa et al., 2007).

Low (undesirable): $A<$ mean $-\frac{1}{2} S d$
Average (rather desirable): mean $-\frac{1}{2} S d \leq B \leq$ mean $\frac{1}{2} S d$
High (desirable): $C>$ mean $+\frac{1}{2} S d$

The face and content validity of the measuring tools were confirmed by gaining the opinions of some faculty members of the Department of Agricultural Extension and Education. Also, given the available studies, some parts of the measuring instruments (self- efficacy beliefs and self-esteem) had acceptable validity and reliability. Therefore, to determine the reliability of the tendency for entrepreneurship and other parts (self-beliefs of efficacy and self-esteem) of the measuring tool, a pioneer study was conducted on 30 students outside of the research 


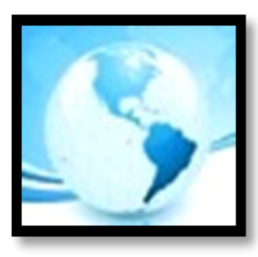

sample. Cronbach's alpha coefficient of $.83, .86$ and .74 was obtained for the tendency for entrepreneurship, selfefficacy and self-esteem inventories, respectively.

SPSS v. 21 was used for data analysis. To interpret and analyze the data, descriptive statistics such as frequency, percentage, mean, and standard deviation along with inferential statistics such as analysis of variance, correlation, and linear regression were used.

\section{FINDINGS AND DISCUSSION}

According to the findings, almost three-quarters of the respondents (74.3\%) were undergraduate students, while the rest of them were postgraduate students. In terms of gender, the number of male was equal to the number of female. Moreover, the parents of more than half of the students (53.3\%) were not entrepreneurs, and only $9.5 \%$ of them stated that their parents were entrepreneurs. Additionally, more than $70 \%$ of respondents are studying in an agricultural branch, and the rest of students are studying natural resources. The total average of respondents is 15.97, distributing from 11.99 to 19.53 . Also, the mean age of the respondents is 22.56 with a standard deviation of 3.1, and the minimum and maximum of 18 and 40 years. The findings are presented in Table 1 in detail.

Table 1

Frequency Distribution of Students According to the Research Variables

\begin{tabular}{cccc}
\hline Variable & Variable Level & Frequency & Frequency Percentage \\
\hline \multirow{3}{*}{ Education } & Undergraduate & 156 & 74.3 \\
& Higher Education & 50 & 23.8 \\
& Unanswered & 4 & 1.9 \\
\hline \multirow{2}{*}{ Gender } & Male & 102 & 48.6 \\
& Female & 102 & 48.6 \\
& Unanswered & 6 & 2.9 \\
Residence & Rural & 66 & 31.4 \\
& Urban & 130 & 61.9 \\
Field of Study & Unanswered & 14 & 6.7 \\
\hline & Agriculture & 153 & 72.9 \\
& Natural Resources & 43 & 20.5 \\
Parental Job & Unanswered & 14 & 6.7 \\
\hline & Two Entrepreneur Parents & 20 & 9.5 \\
& One Entrepreneur Parent & 66 & 31.4 \\
\end{tabular}

As mentioned before, to investigate the tendency for entrepreneurship among the subjects, the scores obtained from the items were added up, and the individuals were categorized into three groups using Interval of Standard Deviation from the Mean (ISDM). The results presented in Table 2 indicate that the majority of the subjects (36.2\%) have relatively a desirable tendency for entrepreneurship. Among the subjects, $33.3 \%$ and $30.5 \%$ of them have a low and desirable tendency toward entrepreneurship (Table 2). 


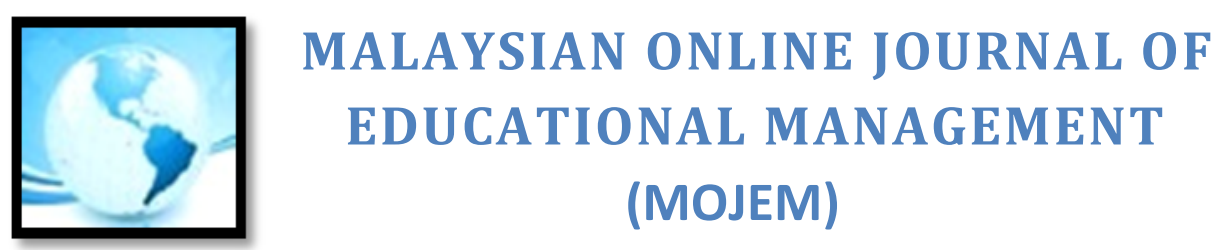

Table 2

Frequency Distribution of the Respondents According to the Tendency for Entrepreneurship

\begin{tabular}{lccc}
\hline Variable Levels & Frequency & $\begin{array}{c}\text { Frequency } \\
\text { Percentage }\end{array}$ & Cumulative Percentage \\
\hline Undesirable (Less than 65.85) & 70 & 33.3 & 33.3 \\
Rather Desirable (65.85-76.57) & 76 & 36.2 & 69.5 \\
Desirable (More than 76.57) & 64 & 30.5 & 100 \\
Total & 210 & 100 & \\
\hline
\end{tabular}

Table 3 indicates the self-esteem among the subjects. Given the described scoring method, the findings indicate that the majority of the subjects $(62.9 \%)$ have moderate self-esteem.

Almost one-fourth of the subjects (24.3\%) have low self-esteem, while nearly one-eighth of them (12.9\%) have high self-esteem. The minimum and maximum scores in self-esteem are 0 and 30 , respectively. In addition, the lowest and highest scores obtained by the respondents are 4 and 30, respectively.

Table 3

Frequency Distribution of Self-Esteem

\begin{tabular}{cccc}
\hline Variable Levels & Frequency & Frequency Percentage & Cumulative Percentage \\
\hline Low & 51 & 24.3 & 24.3 \\
Average & 132 & 62.9 & 87.1 \\
High & 27 & 12.9 & 100 \\
Total & 210 & 100 & \\
\hline
\end{tabular}

To investigate the self- efficacy belief of the subjects, the score obtained from the relevant items were added up, and the individuals were categorized into three groups using ISDM. Results are presented in Table 4. According to this table, $35.7 \%, 35.7 \%$, and $28.6 \%$ of the students have low, high, and moderate self- efficacy belief, respectively.

The $t$-test indicates a significant difference between undergraduate students and postgraduate ones in terms of the tendency for entrepreneurship (Table 5). It means that this tendency is higher among postgraduate students.

Table 4

Frequency Distribution of Self-Efficacy

\begin{tabular}{cccc}
\hline Variable Levels & Frequency & Frequency Percentage & Cumulative Percentage \\
\hline Low & 75 & 35.7 & 35.7 \\
Average & 60 & 28.6 & 64.3 \\
High & 75 & 35.7 & 100 \\
Total & 210 & 100 & \\
\hline
\end{tabular}




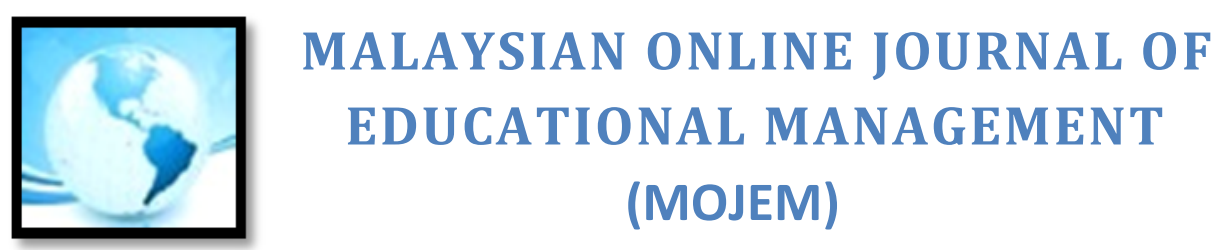

Moreover, the $t$-test was used to investigate the difference between the tendency for entrepreneurship in male and female students. The research findings indicated no significant difference between male and female students in this regard (Table 5). These results are inconsistent with those of research conducted by Strohmeyer (2003), Moog and Backes-Gellner (2013), and Backes-Gellner and Moog (2013), and consistent with the research conducted by Alipour (2013). Similarly, $t$-test was used to investigate the difference between the tendency of agriculture students for entrepreneurship and that of natural resources students. The findings indicated a significant difference between the two groups in terms of the tendency for entrepreneurship (Table 5). It means that the tendency for entrepreneurship was higher in agriculture students. The results of this research are consistent with those of Alipour (2013).

Table 5

Comparison of Tendency for Entrepreneurship in Students According to the Field of Study, Residence, and Education

\begin{tabular}{|c|c|c|c|c|c|}
\hline Variable & & Mean & $S D$ & $t$ & Significance Level \\
\hline \multirow[t]{2}{*}{ Field of Study } & Agriculture & 72.51 & 10.89 & 4.50 & 0.00 \\
\hline & Natural Resources & 65.54 & 8.35 & & \\
\hline \multirow[t]{2}{*}{ Residence } & Rural & 71.54 & 10.12 & 0.37 & 0.71 \\
\hline & Urban & 70.93 & 11.12 & & \\
\hline \multirow[t]{2}{*}{ Gender } & Male & 72.20 & 10.26 & 1.03 & 0.30 \\
\hline & Female & 70.65 & 11.19 & & \\
\hline \multirow[t]{2}{*}{ Education } & Undergraduate & 69.76 & 10.20 & -3.79 & 0.00 \\
\hline & Higher Education & 76.18 & 11.09 & & \\
\hline
\end{tabular}

The Kruskal-Wallis test was used to investigate the tendency for entrepreneurship in the students based on the career of their parents. Results indicated that a significant difference in terms of parental job at the level of $5 \%$ (Table 6). It means that the students with an entrepreneurial parent are more entrepreneurship-oriented than those students without entrepreneurial parents. This result can be attributed to the nature of some entrepreneurial careers, entrepreneurship risk, and finally its consequences for family.

Table 6

Comparison of the Tendency for Entrepreneurship According to the Parental Job

\begin{tabular}{|c|c|c|c|c|c|}
\hline Variable & $\mathbf{N}$ & Graded Mean & Chi Square & $\begin{array}{c}\text { Freedom } \\
\text { Degree }\end{array}$ & $\begin{array}{c}\text { Significance } \\
\text { Level }\end{array}$ \\
\hline Two Entrepreneur Parents & 20 & 65.85 & 7.99 & 2 & 0.01 \\
\hline One Entrepreneur Parent & 66 & 105.17 & & & \\
\hline None & 114 & 103.88 & & & \\
\hline
\end{tabular}

Pearson's correlation test was used to investigate the relationship between the self- efficacy belief, self-esteem, age, academic performance variables (mean) and the tendency for entrepreneurship according to the type and nature of the measuring scale. Results are presented in Table 7. Results indicated a positive and significant correlation between the self- efficacy belief and the tendency for entrepreneurship. In other words, students with higher self- efficacy belief tend more to show entrepreneurial behaviors. Also, the results indicate that self-esteem and the tendency for entrepreneurship are directly and significantly related. It means that higher self-esteem in the students is associated with increased tendency for entrepreneurship, and vice versa. 
In addition, the results indicate a positive and significant relationship between age and entrepreneurship tendency. It means that the respondents' aging is associated with their higher entrepreneurial tendency. However, no significant relationship was observed between the academic performance (mean) of the individuals and their tendency for entrepreneurship.

Table 7

Correlation among Self-Efficacy, Self-Esteem, and the tendency for entrepreneurship in the Respondents

\begin{tabular}{|c|c|c|c|c|}
\hline Variables & Self-efficacy belief & Self-Esteem & $\begin{array}{c}\text { Tendency for } \\
\text { Entrepreneurship }\end{array}$ & Age \\
\hline Self-efficacy belief & 1 & & & \\
\hline Self-Esteem & $0.56 * * *$ & 1 & & \\
\hline Tendency for & $0.53^{* * *}$ & $0.38 * * *$ & 1 & \\
\hline \multicolumn{5}{|l|}{ Entrepreneurship } \\
\hline Age & 0.08 & 0.03 & $0.19 * *$ & 1 \\
\hline Average & $0.19 *$ & 0.11 & 0.15 & 0.09 \\
\hline
\end{tabular}

Multivariate stepwise regression was used to determine the capability of self- efficacy belief and self-esteem variables in predicting the students' tendency for entrepreneurship. Therefore, these two variables were used in regression analysis. According to the results of Table 8 , the value of $F$ obtained from ANOVA was significant at the level of $1 \%$, indicating a linear relationship between the predictive variable and the dependent variable. In this regard, only the variable of self- efficacy belief was included into the regression model. According to the beta values, the variable of self- efficacy belief influences the tendency for entrepreneurship, and one-standard deviation change in this variable is associated with 0.53 -standard-deviation change in the dependent variable. In other words, the impact factor of self- efficacy belief $(\beta=0.53)$ indicates that this variable can predict the changes in self- efficacy belief. It means that higher self-efficacy belief is associated with higher tendency for entrepreneurship in students, and vice versa. According to the adjusted value of $R^{2}$, self- efficacy belief variable is capable of predicting $27 \%$ of changes in the dependent variable. Considering the multivariate regression model, the following equation can predict the tendency for entrepreneurship:

$Y=42.49+0.51 \times 1$

Where, $Y$ is the tendency for entrepreneurship and $X 1$ is the self- efficacy belief. In Table 8 , a summary of regression analysis information is indicated.

Table 8

The Summary of Information from the Stepwise Regression Analysis for the Dependent Variable, i.e. Tendency for Entrepreneurship

\begin{tabular}{cccccc}
\hline Variable & B & SEB & BETA & t & Sig. $\boldsymbol{t}$ \\
\hline Self-efficacy belief & 0.51 & 0.06 & 0.53 & 8.94 & 0.00
\end{tabular}

Multiple $R=0.53, R^{2}=0.28, R^{2}$ Adjust $=0.27$, Constant $=42.49, F=79.97$, Sig. $F=0.000$ 


\section{CONCLUSION AND RECOMMENDATIONS}

The research results indicated that the majority of subjects (36.2\%) had a relatively desirable tendency for entrepreneurship, and in general almost one-third of the subjects (33.3\%) had a low tendency for entrepreneurship. In addition, 30.5\% of them had a desirable tendency for entrepreneurship. These results are backed up by the findings of Backes-Gellner and Moog (2013) and Praag and Ophem (1995).

The research findings indicated that more than one-third of the respondents (35.7\%) had low self- efficacy belief. Given that self- efficacy belief can be developed in people (Bandura, 1997), training programs play a very important role in this regard (vanDinther et al., 2011). Therefore, it is suggested that this subject should be taken into account in the university curricula. Moreover, the research results indicate the probable reduction of selfefficacy belief in educational institutions (Eccles, Wigfield, \& Schiefele, 1998; Wentzel et al., 2009). Therefore, considering the abovementioned findings, conducting studies on the impact of the university on the descending or ascending trend of self- efficacy belief among students is recommended. The research results also indicated that almost one-fourth of the respondents (24.3\%) had low self-esteem, and only $12.9 \%$ of them had high self-esteem. Therefore, doing necessary planning in form of cultural and extracurricular programs is recommended in order to increase student self-esteem.

Furthermore, the research results also indicate that self- efficacy belief and self-esteem have a positive and significant relationship with entrepreneurship tendency. It means that individuals with high self-efficacy belief and self-esteem also have higher tendency for entrepreneurship; whereas those lacking in self- efficacy belief and have low self-esteem show less tendency for entrepreneurship. Therefore, universities are suggested to pay more attention to improving psychological elements influencing entrepreneurship tendency, such as self- efficacy belief and self-esteem, to increase this tendency in students. Thus, given the results of this research, it would be necessary to revise the educational and curricular programs for this matter. Identifying other relevant psychological factors is also recommended to increase entrepreneurship tendency in students.

The results also indicate that aging increases entrepreneurship tendency in students. Further study on this subject is recommended to discover the reason for this and to reach a final verdict. The findings indicate that entrepreneurship tendency of postgraduate students is higher than that of undergraduate students. Given that showing entrepreneurial behaviors requires an opportunity as well as willingness, officials are suggested to make efforts to create and develop entrepreneurial opportunities and to develop this behavior in individuals. The results of regression analysis indicate that the variable of self- efficacy belief is capable of explaining $27 \%$ of the changes in the tendency for entrepreneurship. Therefore, performing more studies on the factors influencing the tendency for entrepreneurship is recommended.

\section{REFERENCES}

Alipour, H. (2013). Investigation on tendency and mentality to entrepreneurship of students in agricultural field in Shiraz township. Journal of Agricultural Education Administration Research, 23, 33-46.

Ardichvili, A., Cardozo, R., \& Ray, S. (2003). A theory of entrepreneurial opportunity identification and development. Journal of Business Venturing, 18, 105-123.

Backes-Gellner, U., \& Moog, P. (2013). The disposition to become an entrepreneur and the jacks-of-all-trades in social and human capital. The Journal of Socio-Economics, 47, 55-72. 


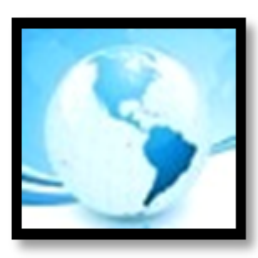

\section{MALAYSIAN ONLINE JOURNAL OF EDUCATIONAL MANAGEMENT (MOJEM)}

Bandura, A. (1997). Self-efficacy: The exercise of control. New York, NY: Worth Publishers.

Barani, S., \& Zarafshani, K. (2009) a determination of the effect of attitude towards entrepreneurship, social norms and self-efficacy in predicting entrepreneurial intentions among rural development management students at Payam-e-Nour University, Keramnshah. Iranian Journal of Agricultural Economics and Development, 402(3), 91-99. (In Farsi).

Barkhordary, M., Jalalmanesh, S., \& Mahmodi, M. (2009). The relationship between critical thinking disposition and self-esteem in Nursing students. Iranian Journal of Medical Education, 9(1), 13-19.(In Farsi).

Chen, C. C., Greene, P. G., \& Crick, A. (1998). Does entrepreneurial self-efficacy distinguish entrepreneurs from managers? Journal of Business Venturing, 13(4), 295-316.

Christensen, A. J., Martin, R., \& Smyth, J. M. (2014). Encyclopedia of health psychology: Springer.

Chu, A. Y. M. (2008). Psychosocial influences of computer anxiety, computer confidence, and computer self-efficacy with online health information in older adults. ProQuest.

Diseth, Å., Meland, E., \& Breidablik, H. J. (2014). Self-beliefs among students: Grade level and gender differences in self-esteem, self-efficacy and implicit theories of intelligence. Learning and Individual Differences, 35, 1-8.

Drnovsek, M., \& Erikson, T. (2005). Competing models of entrepreneurial intentions. Economic and Business Review for Central and South-Eastern Europe, 7(1), 55-71.

Eccles, J. S., Wigfield, S., \& Schiefele, U. (1998). Motivation to succeed. In. W. Damon (Series Ed.) \& N. Eisenberg (Vol. Ed.), Handbook of child psychology Vol. 3: Social emotional, and personality development (pp. 10171095).

Faria, J. R., Cuestas, J. C., \& Mourelle, E. (2010). Entrepreneurship and unemployment: A nonlinear bidirectional causality? Economic Modelling, 27(5), 1282-1291.

Gangadharappa, V., Pramod, T., \& Shiva, H.(2007). Gastric floating drug delivery systems: A review. Indian J Pharm Ed Res., 41, 295-305.

Hassanpur, R., Hosseini, C., \& Safari, C. (2013). Reviewing relationship between self-efficacy with tendency to individual entrepreneurship (Case study: Faculty of Humanities of Shahed University) . Paper presented at the Conference on Knowledge -Based Entrepreneur and Technology, University of Mazandaran. 15-16 May. Retrieved from http://www.civilica.com/Paper-CCC01-CCC01 075.html (In Farsi).

Javan, R. S. (2014). The relationship between personality traits and entrepreneurial intentions. Entrepreneurship and Innovation Management Journal, 2(1), 22-33.

Kumar, S., Vifenda, A. T., Brigitta, M., \& Valerie. (2013). Students' willingness to become an entrepreneur: A survey of non-Business students of President University. Journal of Business and Management, 15(2), 94-102.

Lucas, W. A., \& Cooper, S. Y. (2004). Enhancing self-efficacy to enable entrepreneurship: the case of CMI's connections. MIT Sloan working paper 


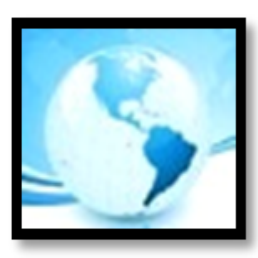

\section{MALAYSIAN ONLINE JOURNAL OF EDUCATIONAL MANAGEMENT (MOJEM)}

Luthans, F., Stajkovic, A. D., \& Ibrayeva, E. (2000). Environmental and psychological challenges facing entrepreneurial development in transitional economies. Journal of World Business, 35(1), 95-110.

Mohamadi, H., Ebadallah, A., \& Jahromi, S. A. (2011). Studying relationship between personality traits and tendency to entrepreneurship. Journal of Society and women, 1, 1-20.

Mojarradi, G., Zamani, H., \& Gholipour, A. (2008). Analysis of job expectations and their effects on institutionalization of private insurance agency for agricultural products (the case of Fars Province). Iranian Agricultural Extension and Education Journal, 3(2), 15-29. (In Farsi).

Moog, P., \& Backes-Gellner, U. (2009). Social capital and the willingness to become self-employed: Is there a difference between women and men? Int. Stud. Manag.Organ. 39 (2), 33-64.

Moriano, J. A. L., \& Gorgievski, M. (2007). Psychology of entrepreneurship: Research and reduction. Spain: UNED.

Mukhopadhyay, C., Akhilesh, K. B., Srinivasan, R., Gurtoo, A., Ramachandran, P., Iyer, P. P., \& Subrahmanya, H. B. (2013). Driving the Economy through Innovation and Entrepreneurship: Emerging Agenda for Technology Management. Springer.

Noorollahenoorivandi, A., \& Mirdamadi, M. (2010). Identifying factors improvement entrepreneurship willingness among agricultural extension expert in Khuzestan province. Journal of Agricultural Extension and Education Research, 3(3), 1-10.

Pajares, F. (1997). Current directions in self-efficacy research. Advances in motivation and achievement, 10(149), 149.

Plummer, D. (2014). Helping adolescents and adults to build self-esteem: A photocopiable resource book. London, UK: Jessica Kingsley.

Praag, C. M. V., \& Ophem, H. V. (1995), Determinants of willingness and opportunity to start as an entrepreneur. Kyklos, 48(4), 513-540.

Pyszczynski, T., Greenberg, J., Solomon, S., \& Arndt, J. (2004). Why do people need self-esteem? A theoretical and empirical review. Psychological Bulletin, 130(3), 435-468.

Remeikiene, R., \& Startiene, G. (2015). Does the interaction between entrepreneurship and unemployment exist? Economics and Management (14), 903-911.

Robinson, P. B., Stimpson, D. V., Huefner, J. C., \& Hunt, H. K. (1991). An attitude approach to the prediction of entrepreneurship. Entrepreneurship theory and practice, 15(4), 13-31.

Schunk, D. H. (1995). Self-efficacy and education and instruction. In Self-efficacy, adaptation, and adjustment (pp. 281-303). Springer US.

Shane, S., Locke, E. A., \& Collins, C. J. (2003). Entrepreneurial motivation. Human Resource Management Review, 13(2), 257-279. 


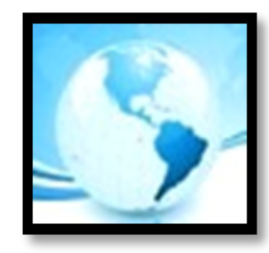

\section{MALAYSIAN ONLINE JOURNAL OF EDUCATIONAL MANAGEMENT (MOJEM)}

Sharf, R. (2015). Theories of psychotherapy \& counseling: Concepts and cases. Cengage Learning.

Shokrkon, H., M. BoroomanNasab, B.Najarian, \& ShahnyYeylaghi, M. (2002). Of simple and multiple relationships, creativity, entrepreneurial achievement and self-esteem martyr Chamran University. Journal of Educational Science and Psychology, 9(3 -4), 1 - 24. (In Farsi)

Sowislo, J. F., \& Orth, U. (2013). Does low self-esteem predict depression and anxiety? A meta-analysis of longitudinal studies. Psychological Bulletin, 139(1), 213-240.

Strohmeyer, R. (2003, June). Gender differences in self-employment: Does education matter. Presentation at the ICSB, 48th World Conference, Belfast.

vanDinther, M., Dochy, F., \& Segers, M. (2011). Factors affecting students' self-efficacy in higher education. Educational Research Review, 6(2), 95-108.

Waight, P. I. (2006). Attachment, Anxiety and the Entrepreneurial Mind: The relationship between adult attachment style and entrepreneurship (Doctoral dissertation, Griffith Business School).

Welsh, J. A., \& White, J. F. (1981). Converging on characteristics of entrepreneurs. In K. H. Vesper (Ed.), Frontiers of entrepreneurship research (pp. 504-515). Wellesley, MA: Babson Center for Entrepreneurial Studies.

Wentzel, K., Wigfield, A., \& Miele, D (2009). Handbook of motivation at school. London, UK: Routledge.

Zampetakis, L. A., Kafetsios., K, Bouranta, N., Dewett, T., \& Moustakis. V. S. (2008). On the relationship between emotional intelligence and entrepreneurial attitudes and intentions. International Journal of Entrepreneurial Behaviour \& Research, 15(6), 595-618. 